СМ. Ю. НИЧИТАЙЛО, О. П. КОНДРАТЮК, Ю. О. ХІЛЬКО, П. В. ОГОРОДНІК, А. Г. ДЕЙНІЧЕНКО, В. А. КОНДРАТЮК, Н. А. ЄРМАК, Т. А. ЮСУПОВ, І. І. БУЛІК, В. А. ДЄЄВ

ДУ “Національний інститут хірургії та трансплантології імені О. О. Шалімова”, Київ

\title{
Динаміка показників гепатодепресивного, цитолітичного і холестатичного синдромів та частота ускладнень у хворих із механічною жовтяницею пухлинного генезу після ендоскопічної і лапароскопічної передопераційної декомпресії загальної жовчної протоки
}

\begin{abstract}
Мета роботи: з’ясувати динаміку показників гепатодепресивного, цитолітичного і холестатичного синдромів, а також частоту ускладнень у хворих із механічною жовтяницею пухлинного генезу після ендоскопічної і лапароскопічної передопераційної декомпресії загальної жовчної протоки.

Матеріали і методи. В основу роботи покладено аналіз історій хвороб 60 хворих на пухлини біліопанкреатодуоденальної зони з синдромом механічної жовтяниці, які перебували на лікуванні в ДУ “Національний інститут хірургії та трансплантології імені О. О. Шалімова” НАМН України з 2011 до 2017 р. Усім пацієнтам проведено декомпресію загальної жовчної протоки як перший - підготовчий етап, з подальшим радикальним операційним втручанням із лапаротомного доступу. У першій групі виконували ендоскопічну декомпресію жовчних шляхів, заводячи катетер ретроградно через великий дуоденальний сосочок. У другій групі лапароскопічно виконували холецистектомію, а далі катетер заводили антеградно через міхурну протоку. Додатково через праве підребер’я дренували ложе жовчного міхура. Основне операційне втручання виконували не раніше, ніж через 14 діб. Всім пацієнтам виконували загальноклінічні, спеціальні, лабораторні та інструментальні методи обстеження. До операції, а також через 3, 7 і 14 діб у пацієнтів у сироватці крові за загальновідомими методами визначали маркери гепатодепресивного, цитолітичного і холестатичного синдромів: вміст загального білірубіну, активність аланінамінотрансферази (АлАТ), лужної фосфатази (ЛФ), протромбіновий час, а також частоту ускладнень у віддаленому післяопераційному періоді.

Результати досліджень та їх обговорення. У всіх пацієнтів з обтураційним холестазом пухлинного походження на момент госпіталізації спостерігали збільшення показників - маркерів гепатодепресивного, цитолітичного і холестатичного синдромів. У ході виконання декомпресії, незалежно від способу, до 14 доби суттєво спадала активність у сироватці крові АлАТ та ЛФ, знижувався вміст загального білірубіну, а також величина протромбінового часу, які не досягали рівня загальноприйнятої норми. За більшістю досліджуваних маркерів холестазу ефективність обох методів декомпресії загальної жовчної протоки була практично однакова, однак величина протромбінового часу після лапароскопічної декомпресії через 14 діб була істотно менша. У віддаленому післяопераційному періоді після лапароскопічної декомпресії частота ускладнень була у 5,33 раза менша, ніж після ендоскопічного втручання, що дозволяє рекомендувати ширше впровадження лапароскопічних технологій з метою декомпресії жовчних шляхів як першого етапу перед радикальним видаленням пухлин біліопанкреатодуоденальної зони.
\end{abstract}

Ключові слова: лапароскопічна декомпресія; обтураційний холестаз; періампулярна пухлина; маркери холестазу.

Постановка проблеми і аналіз останніх досліджень та публікацій. Пухлини біліопанкреатодуоденальної зони належать до актуальних проблем сучасної абдомінальної хірургії. Їх частота, за даними різних авторів, коливається від 1 до 15 \% [1, 2]. Незважаючи на досягнення у своєчасній діагностиці пухлин цієї локалізацї, в більшості випадків виникає обтурація жовчних шляхів із розвитком синдрому механічної жовтяниці [3]. За цих умов настає ураження гепатоцитів і зниження функціональної спроможності печінки. У зв’язку 3 цим, при курабельних пухлинах операційне втручання виконують у два етапи. На першому етапі проводять декомпресію жовчних шляхів, що сприяє відновленню функції печінки, на другому - виконують радикальне видалення пухлини.

3 розвитком міні-інвазивних технологій декомпресію жовчних шляхів проводять або ретро- градно з використанням ендоскопії, або антеградно 3 використанням лапароскопічного методу. Ліквідовуючи інтоксикацію, жовтяницю, холангіт, біліодуоденальне дренування створює умови для подальшого радикального втручання [4]. Проте до сьогодні вибір способу біліодекомпресійних втручань у хворих на рак органів періампулярної зони, ускладнений механічною жовтяницею, залишається предметом підвищеної уваги і дискусій фахівців [5, 6].

Лапароскопічний метод дозволяє створити умови для повноцінної передопераційної підготовки пацієнтів, провести ретельне обстеження жовчних шляхів, а в ряді випадків виконати їх адекватну санацію, що сприяє покращенню результатів подальшого лікування [7]. Разом із тим, автори вважають, що результати лікування механічної жовтяниці пухлинної етіології можна по- 
кращити за рахунок використання методів внутрішнього дренування жовчних проток [8]. Тому вибір варіантів передопераційного жовчовідведення при пухлинній обструкції до сьогодні не має недостатньо обгрунтованих об’єктивних критеріїв.

Мета роботи: з'ясувати динаміку показників гепатодепресивного, цитолітичного і холестатичного синдромів, а також частоту ускладнень у хворих із механічною жовтяницею пухлинного генезу після ендоскопічної і лапароскопічної передопераційної декомпресії загальної жовчної протоки.

Матеріали і методи. В основу роботи покладено аналіз історій хвороб 60 хворих на пухлини біліопанкреатодуоденальної зони з синдромом механічної жовтяниці, які перебували на лікуванні в ДУ “Національний інститут хірургії та трансплантології імені О. О. Шалімова” НАМН України з 2011 до 2017 р. Усім пацієнтам проведено декомпресію загальної жовчної протоки як перший - підготовчий етап, з подальшим радикальним операційним втручанням із лапаротомного доступу. Серед пацієнтів було 39 чоловіків і 21 жінка. Вік пацієнтів коливався від 39 до 82 років і в середньому становив $(64,7 \pm 2,8)$ року $(\mathrm{p}=0,05)$. Усіх пацієнтів розподілили на 2 групи (по 30 осіб), які були рандомізовані за віком і статтю, тривалістю жовтяниці, рівнем загального білірубіну, стадією онкологічного захворювання та частотою супутньої патології.

У першій групі виконували ендоскопічну декомпресію жовчних шляхів, заводячи катетер ретроградно через великий дуоденальний сосочок. У другій групі лапароскопічно виконували холецистектомію, а далі катетер заводили антеградно через міхурну протоку. Додатково через праве підребер’я дренували ложе жовчного міхура.
Основне оперативне втручання виконували не раніше, ніж через 14 діб.

Всім пацієнтам виконували загальноклінічні, спеціальні, лабораторні та інструментальні методи обстеження. До операції, а також через 3, 7 i 14 діб у пацієнтів в сироватці крові за загальновідомими методами визначали маркери гепатодепресивного, цитолітичного і холестатичного синдромів: вміст загального білірубіну, активність аланінамінотрансферази (АлАТ) та лужної фосфатази (ЛФ), а також протромбіновий час. У віддаленому післяопераційному періоді оцінювали частоту післяопераційних ускладнень.

Отримані цифрові дані піддавали статистичному аналізу. Відмінності між групами порівняння оцінювали з використанням непараметричного критерію Манна-Уітні.

Результати досліджень та їх обговорення. Згідно 3 даними таблиці 1, у доопераційний період в обраних групах був практично однаковий рівень вмісту загального білірубіну в сироватці крові, який перевищував 300 ммоль $\pi^{-1}$. Після виконання ендоскопічної декомпресії показник статистично вірогідно знижувався: через 3 доби - на 21,0 \% ( $<<0,05)$, через 7 діб - у 2,88 раза $(\mathrm{p}<0,05)$, через 14 діб - у 11,69 раза ( $<<0,05)$.

Аналогічна динаміка була й після лапароскопічної декомпресії. Вміст загального білірубіну в сироватці крові через 3 доби післяопераційного періоду знизився на 26,0 \% ( $<<0,05)$, через 7 діб - у 3,56 раза $(\mathrm{p}<0,05)$, через 14 діб - у 12,40 раза $(\mathrm{p}<0,05)$.

В обох групах у кожен наступний термін спостереження показник був статистично вірогідно менший, ніж у попередній $(\mathrm{p}<0,05)$.

При порівнянні груп пацієнтів встановили, що через 3 і 14 діб післяопераційного періоду не спо-

Таблиця 1. Вміст загального білірубіну в сироватці крові (мкмоль-л ${ }^{-1}$ ) після ендоскопічної і лапароскопічної передопераційної декомпресії загальної жовчної протоки при механічній жовтяниці пухлинного генезу, Me (QL; QA) - медіана (верхній і нижній квартилі)

\begin{tabular}{||c|c|c|c|c||}
\hline \multirow{2}{*}{ Група хворих } & \multirow{2}{*}{ При госпіталізації } & \multicolumn{3}{|c||}{ Термін обстеження після операції } \\
\cline { 3 - 5 } & & 3 доба & 7 діб & 14 діб \\
\hline Ендоскопічна & 304,0 & $240,3^{*}$ & $105,5^{* 3}$ & $26,0^{* 3,7}$ \\
декомпресія (n=30) & $(253,0 ; 352,0)$ & $(186,0 ; 299,5)$ & $(89,0 ; 124,8)$ & $(20,0 ; 33,0)$ \\
\hline Лапароскопічна & 310,0 & $229,4^{*}$ & $87,2^{* 3}$ & $25,0^{* 3,7}$ \\
декомпресія (n=30) & $(247,0 ; 341,5)$ & $(182,8 ; 252,7)$ & $(69,5 ; 96,0)$ & $(22,5 ; 30,0)$ \\
\hline $\mathrm{P}$ & $>0,05$ & $>0,05$ & $<0,05$ & $>0,05$ \\
\hline \hline
\end{tabular}

Примітки. Тут і в інших таблицях:

1) * - відмінності стосовно доопераційного періоду статистично вірогідні (р<0,05);

2) р - вірогідність відмінностей між групами хворих, яким виконували ендоскопічну і лапароскопічну передопераційну декомпресію загальної жовчної протоки.

3) ${ }^{3,7}$ - відмінності стосовно 3 і 7 діб після операції статистично вірогідні (p<0,05). 
стерігали статистично значущих відмінностей у величині вмісту загального білірубіну в сироватці крові (p>0,05), тоді як через 7 діб у групі, в якій виконували лапароскопічну декомпресію загальної жовчної протоки показник був істотно меншим (на 17,3 \%, p<0,05).

Важливу роль в оцінюванні функціонального стану печінки і прийнятті рішення щодо проведення операційного втручання відіграють показники гепатодепресивного синдрому, серед яких важливе діагностичне значення має величина протромбінового часу.

Обстеження показали (табл. 2), що в обох групах пацієнтів протромбіновий час був практично однаковий $(p>0,05)$ і значно перевищував рівень норми.

Після проведення ендоскопічної декомпресії показник поступово знижувався порівняно з величиною при госпіталізації: через 3 доби - на 7,7 \%, через 7 діб - на 23,1 \%, через 14 діб - на 30,8 \%. У всіх випадках відмінності стосовно доопераційного періоду були статистично вірогідні $(\mathrm{p}<0,05)$.

Аналогічно показник знижувався й після лапароскопічної декомпресії: через 3 доби - на 8,0 \% ( $<<0,05)$, через 7 діб - на 20,0 \% ( $<00,05)$, через 14 діб - на 40,0 \% ( $<<0,05)$.

При порівнянні двох груп встановили, що через 3 і 7 діб після декомпресії не спостерігалися статистично значущі відмінності величини протромбінового часу залежно від виду декомпресії (p>0,05). Водночас через 14 діб величина досліджуваного показника у групі пацієнтів, яким виконували лапароскопічну декомпресію, була істотно менша (на 16,7 \%, p<0,05).

Аналізуючи динаміку досліджуваного показника, встановили, що у кожен наступний термін спостереження показник в обох групах ставав статистично вірогідно меншим, ніж у попередній $(\mathrm{p}<0,05)$.

У свою чергу, активність АлАТ у групах обстеження при госпіталізації в обох групах порівняння статистично вірогідно не відрізнялася $(\mathrm{p}>0,05)$ і значно перевищувала рівень загальноприйнятої норми (табл. 3).

Після виконання ендоскопічної декомпресії, порівняно з величиною при госпіталізації, активність АлАТ у сироватці крові поступово знижувалася: через 3 доби - на 17,5 \% (p<0,05), через 7 діб - на 41,9 \% ( $<0,05)$, через 14 діб - у 2,68 раза $(\mathrm{p}<0,05)$.

Аналогічно показник знижувався й після лапароскопічної декомпресії: через 3 доби - на 24,5 \% ( $<<0,05)$, через 7 діб - на 46,8 \% ( $<0,05)$, через 14 діб - у 2,98 раза $(\mathrm{p}<0,05)$.

При порівнянні груп обстежених пацієнтів, 3'ясували, що у всі терміни спостереження між групами порівняння не спостерігалися істотні відмінності $(\mathrm{p}>0,05)$.

У динаміці активність АлАТ у сироватці крові у кожен наступний термін спостереження бу-

Таблиця 2. Протромбіновий час (с) після ендоскопічної і лапароскопічної передопераційної декомпресії загальної жовчної протоки при механічній жовтяниці пухлинного генезу, Me (QL; QA) - медіана (верхній i нижній квартилі)

\begin{tabular}{|c|c|c|c|c|}
\hline \multirow{2}{*}{ Група хворих } & \multirow{2}{*}{ При госпіталізації } & \multicolumn{3}{|c|}{ Термін обстеження після операції } \\
\hline & & 3 доба & 7 діб & 14 діб \\
\hline $\begin{array}{l}\text { Ендоскопічна } \\
\text { декомпресія }(n=30)\end{array}$ & $\begin{array}{c}26,0 \\
(24,3 ; 26,0)\end{array}$ & $\begin{array}{c}24,0^{*} \\
(23,0 ; 25,0)\end{array}$ & $\begin{array}{c}20,0^{* 3} \\
(18,3 ; 21,8)\end{array}$ & $\begin{array}{c}18,0^{* 3,7} \\
(17,0 ; 19,0)\end{array}$ \\
\hline $\begin{array}{l}\text { Лапароскопічна } \\
\text { декомпресія }(\mathrm{n}=30)\end{array}$ & $\begin{array}{c}25,0 \\
(24,0 ; 26,0)\end{array}$ & $\begin{array}{c}23,0^{*} \\
(22,0 ; 24,0)\end{array}$ & $\begin{array}{c}20,0^{* 3} \\
(19,3 ; 21,8)\end{array}$ & $\begin{array}{c}15,0^{* 3,7} \\
(14,2 ; 16,0)\end{array}$ \\
\hline $\mathrm{P}$ & $>0,05$ & $>0,05$ & $>0,05$ & $<0,05$ \\
\hline
\end{tabular}

Таблиця 3. Активність АлАТ в сироватці крові (мОд/л) після ендоскопічної і лапароскопічної передопераційної декомпресії загальної жовчної протоки при механічній жовтяниці пухлинного генезу, Me (QL; QA) - медіана (верхній і нижній квартилі)

\begin{tabular}{||c|c|c|c|c||}
\hline \multirow{2}{*}{ Група хворих } & \multirow{2}{*}{ При госпіталізації } & \multicolumn{2}{|c||}{ Термін обстеження після операції } \\
\cline { 3 - 5 } & & 3 доба & 7 діб & 14 діб \\
\hline Ендоскопічна & 112,2 & $92,6^{*}$ & $65,2^{* 3}$ & $41,8^{* 3,7}$ \\
декомпресія (n=30) & $(103,5 ; 126,5)$ & $(84,5 ; 104,8)$ & $(59,5 ; 73,8)$ & $(38,2 ; 47,3)$ \\
\hline Лапароскопічна & 118,8 & $89,7^{*}$ & $63,2^{* 3}$ & $39,8^{* 3,7}$ \\
декомпресія(n=30) & $(100,6 ; 128,7)$ & $(82,0 ; 104,4)$ & $(53,3 ; 73,5)$ & $(33,8 ; 59,8)$ \\
\hline $\mathrm{P}$ & $>0,05$ & $>0,05$ & $>0,05$ & $>0,05$ \\
\hline
\end{tabular}


ла статистично вірогідно менша, ніж у попередній термін $(\mathrm{p}<0,05)$.

Обтурація жовчних шляхів супроводжується підвищенням вмісту в сироватці крові печінкового ізоферменту лужної фосфатази, завдяки якому зростає загальна активність ЛФ.

Дослідження показали, що при госпіталізації в обох групах пацієнтів активність ЛФ у сироватці крові (табл. 4) значно перевищувала загальноприйняту норму, проте між групами статистично вірогідно не відрізнялася ( $>0,05)$.
Після виконання ендоскопічної декомпресії загальної жовчної протоки показник поступово знижувався порівняно з рівнем при госпіталізації і через 3 доби ставав менше на 6,8 \% (p<0,05), через 7 діб - у 2,36 раза ( $<<0,05)$, через 14 діб - у 2,82 раза $(\mathrm{p}<0,05)$.

Аналогічно активність ЛФ сироватки крові знижувалася порівняно з рівнем при госпіталізації й після лапароскопічної декомпресії: через 3 доби - на 7,4 \% ( $<00,05)$, через 7 діб - у 2,45 раза $(\mathrm{p}<0,05)$, через 14 діб - у 2,97 раза $(\mathrm{p}<0,05)$.

Таблиця 4. Активність лужної фоссратази у сироватці крові (мОд/л) після ендоскопічної і лапароскопічної передопераційної декомпресії загальної жовчної протоки при механічній жовтяниці пухлинного генезу, Me (QL; QA) - медіана (верхній і нижній квартилі)

\begin{tabular}{||l|c|c|c|c||}
\hline \multirow{2}{*}{ Група хворих } & \multirow{2}{*}{ При госпіталізації } & \multicolumn{3}{|c||}{ Термін обстеження після операції } \\
\cline { 3 - 5 } & & 3 доба & 7 діб & 14 діб \\
\hline $\begin{array}{l}\text { Ендоскопічна } \\
\text { декомпресія }(\mathrm{n}=30)\end{array}$ & 334,6 & $311,8^{*}$ & $141,5^{* 3}$ & $118,5^{* 3,7}$ \\
\hline Лапароскопічна & $(307,6 ; 372,6)$ & $(287,5 ; 249,2)$ & $(129,4 ; 159,6)$ & $(97,3 ; 140,8)$ \\
декомпресія $(\mathrm{n}=30)$ & $(379,0 ; 357,1)$ & $(251,2 ; 349,7)$ & $(110,8 ; 154,2)$ & $(104,6 ; 125,5)$ \\
\hline$p$ & $>0,05$ & $>0,05$ & $>0,05$ & $>0,05$ \\
\hline
\end{tabular}

Слід зауважити, що у кожен наступний термін спостереження в обох групах пацієнтів активність ЛФ сироватки крові була статистично вірогідно менша, ніж у попередній ( $<0,05)$, проте між групами показник у всі терміни спостереження статистично вірогідно не відрізнявся (р>0,05).

Статистично значущих відмінностей за активністю ЛФ у сироватці крові між групами спостереження не встановили.

Аналіз ускладнень, які виникли перед радикальним операційним втручанням у пацієнтів із пухлинами органів біліопанкреатодуоденальної зони, яким виконували передопераційну декомпресію жовчних шляхів з використання різних технологій, показав (рис. 1), що після лапароскопічної декомпресії частота ускладнень становила $(10,0 \pm 5,5)$ \%: у трьох пацієнтів виник холангіт.

У свою чергу, після ендоскопінчої декомпресії жовчних шляхів ускладнення встановили у $(33,3 \pm 8,6) \%$, що виявилося статистично вірогідно більшим, ніж серед пацієнтів із лапароскопічною доопераційною декомпресією ( $<<0,05)$. У трьох пацієнтів виник рефлюкс-холангіт, у п’яти - гострий панкреатит, у двох кровотеча з місця папілотомії.

Таким чином, у пацієнтів з обтураційним холестазом пухлинного походження на час госпіталізації спостерігали збільшення показників -

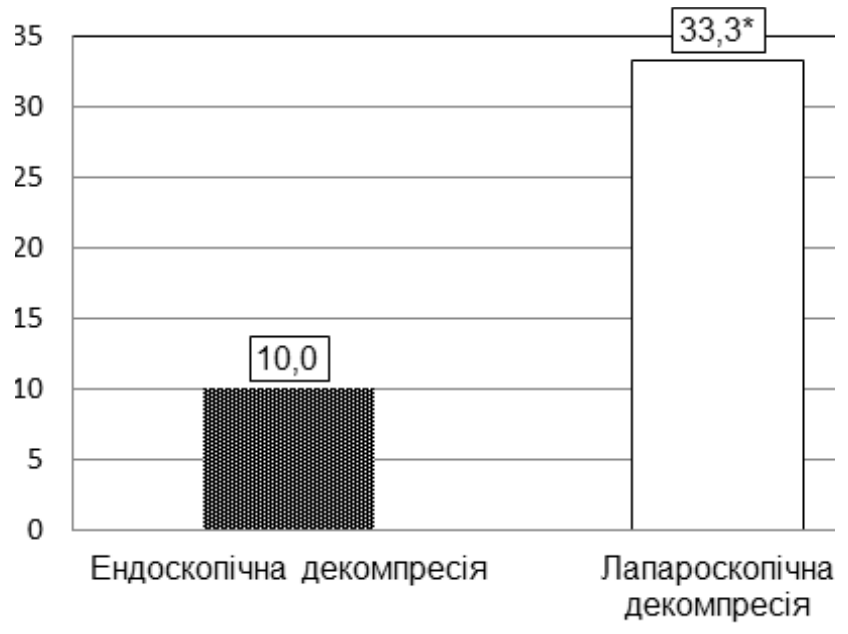

Рис. 1. Частота ускладнень після ендоскопічної і лапароскопічної доопераційної декомпресії загальної жовчної протоки при механічній жовтяниці пухлинного генезу (примітка: *- $<<0,001)$.

маркерів гепатодепресивного, цитолітичного i холестатичного синдромів. В ході виконання декомпресії, незалежно від способу, до 14 доби суттєво знижується у сироватці крові вміст загального білірубіну, протромбіновий час, спадає активність у сироватці крові, АлАТ та ЛФ, проте не досягає рівня загальноприйнятої норми. Привертає увагу факт, що за більшістю маркерів холестазу ефективність ендоскопічної і лапароскопічної декомпресії є практично однаковою. 
Отримані результати свідчать, що обидва методи суттєво впливають на зниження процесів цитолізу та холестазу. Це зумовлено декомпресією жовчних шляхів, внаслідок чого істотно знижується інтоксикація, покращується мікроциркуляція печінки, відновлюються функціональні можливості гепатоцитів [4]. За таких умов значно зростають шанси успішного виконання другого етапу операції - радикального видалення пухлини.

Однак протромбіновий час за умов лапароскопічної декомпресії стає вірогідно нижчим, порівняно з ендоскопічною декомпресією. Отриманий результат із певною часткою ймовірності дозволяє припустити, що за умов лапароскопічної декомпресії протягом перших 14 діб створюються кращі умови для відновлення функціонального стану печінки. Можна припустити, що технологічно заведення катетера ретроградно є більш травмуючою процедурою, ніж антеградно. Крім цього, очевидно важливу роль відіграє хролецистектомія, яку виконують у ході лапароскопічного втручання. Це знижує прояви запалення, яке, як правило, має місце у застійному жовчному міхурі, та потрапляння у жовчні ходи в'язкої міхурної жовчі, яка погіршує іï пасаж, навіть при ретроградно встановленому дренажі.

Яскравим доказом наведених припущень $€$ аналіз ускладнень, які виникали в пацієнтів після виконання доопераційної декомпресії та радикальної операції. У випадку лапароскопічної декомпресії частота ускладнень була у 5,33 раза менша, ніж після ендоскопічного втручання.

Все наведене вище дозволяє рекомендувати ширше впровадження лапароскопічних технологій з метою декомпресії жовчних шляхів як пер-

\section{СПИСОК ЛІТЕРАТУРИ}

1. Ishihara S. Epidemiology of biliary tract cancer - comparison with other country / S. Ishihara, A. Horiguchi // Nihon Rinsho. 2015. - Vol. 73 (Suppl. 3). - P. 466-470.

2. Morine Y. Nation wide survey of pancreaticobiliary maljunction / Y. Morine, M. Shimada, H. Ishibashi // Nihon Shokakibyo Gakkai Zasshi. - 2014. - Vol. 111, No. 4. - P. 699-705.

3. Малярчук В. И. Билиопанкреатодуоденальный рак / В. И. Малярчук, А. Е. Климов, Ю. Ф. Пауткин. - М. : Рос. ун-т дружбы народов, 2009. - 444 с.

4. Хрусталева М. В. Эндоскопическое транспапиллярное дуоденобилиарное дренирование в лечении механической желтухи / М. В. Хрусталева, Ю. И. Галлингер // Анналы Росс. науч. центра хирургии РАМН. - 2001. - № 10. - С. 45-48.

5. Обоснование хирургической тактики при механической желтухе (аналитический обзор литературы) / С. М. Елисеев,

\section{REFERENCES}

1. Ishihara, S., \& Horiguchi, A. (2015). Epidemiology of biliary tract cancer - comparison with other country. Nihon Rinsho, 73 (3), 466-470. шого етапу перед радикальним видалення пухлин біліопанкреатодуоденальної зони.

Висновки. 1. У пацієнтів з обтураційним холестазом пухлинного походження на час госпіталізації спостерігають збільшення показників маркерів гепатодепресивного, цитолітичного і холестатичного синдромів: вміст у сироватці крові загального білірубіну, активності АлАТ та ЛФ, зростання протромбінового часу.

2. В ході виконання декомпресії, незалежно від способу, до 14 доби суттєво знижується у сироватці крові вміст загального білірубіну, активність, АлАТ та ЛФ, проте не досягає рівня загальноприйнятої норми, немає статистично значущих відмінностей за більшістю досліджуваних показників. Проте після виконання лапароскопічної декомпресії загальної жовчної протоки протромбіновий час через 14 діб стає статистично вірогідно меншим, ніж після ендоскопічної декомпресії.

3. Застосування лапароскопічної доопераційної декомпресії жовчних шляхів у пацієнтів 3 механічною жовтяницею пухлинного генезу супроводжується у 5,33 раза меншою частотою ускладнень, ніж у пацієнтів, яким виконували ендоскопічну доопераційну декомпресію.

Перспективи подальших досліджень. У перспективі варто поглибити дослідження з метою визначення основних переваг лапароскопічного методу декомпресії загальної жовчної протоки, порівняно з ендоскопічними, як першого етапу радикального видалення пухлин біліопанкреатодуоденальної зони.

Н. Г. Корнилов, С. П. Чикотеев, Р. Р. Гумеров // Бюл. ВСНЦ CO PAMH. - 2010. - № 5. - С. 233-239.

6. Михайлова С. А. Дренирующие пособия при механической желтухе опухолевой этиологии / С. А. Михайлова // Паллиативная медицина и реабилитация. - 2006. - № 2. C. 22.

7. Никитин Н. А. Лапароскопическое чрескожно-чреспеченочное дренирование желчного пузыря у больных механической желтухой / Н. А. Никитин, Л. Ю. Подгорный, А. Г. Дроздов // Вятск. мед. вестник. - 2002. - № 1. - С. 27.

8. Коновалов Д. Ю. Сравнительная оценка хирургического лечения больных с синдромом механической желтухи опухолевой этиологии / Д. Ю. Коновалов, Э. И. Гумерова, М. Е. Амантурлиева // Акт. пробл. гуманитар. и естеств. наук. - 2014. - № 1-2. - С. 188-192.

2. Morine, Y., \& Ishibashi, H. (2014). Nation wide survey of pancreaticobiliary maljunction. Nihon Shokakibyo Gakkai Zasshi, 111, 4, 699-705. 
3. Malyarchuk, V.I., Klimov, A.Ye., \& Pautkin, Yu.F. (2009). Biliopankreatoduodenalnyy rak [Biliopancreatoduodenal cancer]. Moscow: Ros. un-t druzhby narodov [in Russian].

4. Khrustaleva, M.V., \& Gallinger, Yu.I. (2001). Endoskopicheskoye transpapillyarnoye duodenobiliarnoye drenirovaniye v lechenii mekhanicheskoy zheltukhi [Endoscopic transpapillary duodenobiliary drainage in the treatment of obstructive jaundice]. Annaly Ros. nauch. tsentra khirurgii RAMN - Annals of Russian Scientific Center of Surgery RAMS, 10, 45-48 [in Russian]. 5. Yeliseyev, S.M., Kornilov, N.G., Chikoteyev, S.P., \& Gumerov, R.R. (2010). Obosnovaniye khirurgicheskoy taktiki pri mekhanicheskoy zheltukhe (analiticheskiy obzor literatury) [Justification of surgical tactics in obstructive jaundice (analytical review of literature)]. Byul. VSNTS SO RAMN - Bulletin of the E-SSC of the SB RAMS, 5, 233-239 [in Russian].

6. Mikhaylova, S.A. (2006). Dreniruyushchiye posobiya pri mekha- nicheskoy zheltukhe opukholevoy etiologii [Drainage aids for obstructive jaundice of tumor etiology]. Palliativ. meditsina i reabilitatsiya - Palliative Medicine and Rehabilitation, 2, 22 [in Russian]. 7. Nikitin, N.A., Podgornyy, L.Yu., \& Drozdov, A.G. (2002). Laparoskopicheskoye chreskozhno-chrespechenochnoye drenirovaniye zhelchnogo puzyrya u bolnykh mekhanicheskoy zheltukhoy [Laparoscopic percutaneous-transhepatic drainage of the gallbladder in patients with obstructive jaundice]. Vyatsk. med. vestnik - Vyatsk Medical Journal, 1, 27 [in Russian].

8. Konovalov, D.Yu., Gumerova, E.I., Amanturliyeva, M.Ye. (2014). Sravnitelnaya otsenka khirurgicheskogo lecheniya bolnykh s sindromom mekhanicheskoy zheltukhi opukholevoy etiologii [Comparative evaluation of surgical treatment of patients with obstructive jaundice syndrome of tumor etiology]. Akt. probl. gumanitar. i yestestv. nauk - Actual Problems of Humanitarian and Natural Sciences, 1-2, 188-192 [in Russian].

Отримано 03.10.18

Електронна адреса для листування: khilko304@уаһоo.com

M. Y. NYCHITAYLO, A. P. KONDRATIUK, YU. O. KHILKO, P. V. OGORODNYK, A. G. DEINYCHENKO, V. A. KONDRATIUK, N. A. YERMAK, T. A. YUSUPOV, I. I. BULIK, V. A. DIEIEV

O. Shalimov National Institute of Surgery and Transplantation

\title{
DYNAMICS OF INDICATORS OF HEPATODEPRESSIVE GYTOLYTIC AND CHOLESTATIC SYNDROME AND THE INCIDENCE OF COMPLICATIONS IN PATIENTS WITH MECHANICAL JAUNDICE OF TUMOR GENESIS AFTER ENDOSCOPIC AND LAPAROSCOPIC PREOPERATIVE DECOMPRESSION OF THE COMMON BILE DUCT
}

\begin{abstract}
The aim of the work: to find out the dynamics of indicators of hepatodepressive, cytolytic and cholestatic syndromes, as well as the frequency of complications in patients with mechanical jaundice of tumor genesis after endoscopic and laparoscopic preoperative decompression of the common bile duct.

Materials and Methods. The basis of the work is the analysis of histories of diseases of 60 patients with tumors of the biolipanceratoduodenal zone with a mechanical jaundice syndrome that was treated at the State Medical Service "National Institute of Surgery and Transplantology named after O. Shalimov" NAMS of Ukraine from 2011 to 2017. The bile duct as the first - the preparatory stage with subsequent radical surgical intervention with laparotomic access. In the first group, endoscopic decompression of the biliary tract was performed, the catheter was retrograded through a large duodenal papilla. In the second group, they performed laparoscopic cholecystectomy, and then the catheter was initiated concurrently through the bladder duct. Additionally, through the right hypochondrium drained the bed of the gall bladder. The main surgical intervention was performed not earlier than after 14 days. All patients underwent general clinical, special, laboratory and instrumental methods of examination. Before the operation, as well as in 3, 7 and 14 days in blood serum of patients, known markers of gepatodepressive, cytolytic and cholestatic syndromes were determined: total bilirubin content, alanine aminotransferase (ALT) activity, alkaline phosphatase (LF), prothrombin time, as well as the frequency of complications in the remote postoperative period.

Results and Discussion. In all patients with obstructive cholestasis of tumor origin at the time of hospitalization there was an increase in indicators - markers of hepatodepressive, cytolytic and cholestatic syndromes. In the course of decompression, the activity of serum ALT and LF significantly decreased to 14 days, the content of total bilirubin decreased, as well as the amount of prothrombin time that did not reach the level of the generally accepted norm. For most of the studied cholestasis markers, the effectiveness of both methods of decompression of the common bile duct was practically the same, however, the amount of prothrombin time after laparoscopic decompression in 14 days was significantly lower. In the remote postoperative period after the laparoscopic decompression, the incidence of complications was 5.33 times lower than after endoscopic intervention, which allows for the advent of a wider introduction of laparoscopic technologies for the purpose of decompression of the biliary tract as a first step before the radical removal of the tumors of the bialiopancreatoduodenal zone.
\end{abstract}

Key words: laparoscopic decompression; obstructive cholestasis; periamapal tumor; markers of cholestasis. 
М. Е. НИЧИТАЙЛО, А. П. КОНДРАТЮК, Ю. А. ХИЛЬКО, П. В. ОГОРОДНИК, А. Г. ДЕЙНИЧЕНКО, В. А. КОНДРАТЮК, Н. А. ЕРМАК, Т. А. ЮСУПОВ, И. И. БУЛИК, В. А. ДЕЕВ

гу “Национальный институт хирургии и трансплантологии имени А. А. Шалимова”, Киев

\title{
ДИНАМИКА ПОКАЗАТЕЛЕЙ ГЕПАТОДЕПРЕССИВНОГО, ЦИТОЛИТИЧЕСКОГО И ХОЛЕСТАТИЧЕСКОГО СИНДРОМОВ И ЧАСТОТА ОС.ОЖНЕНИЙ У БОЛЬНЫХ С МЕХАНИЧЕСКОЙ ЖЕЛТУХОЙ ОПУХОЛЕВОГО ГЕНЕЗА ПОС.ЛЕ ЭНДОСКОПИЧЕСКОЙ И ЛАПАРОСКОПИЧЕСКОЙ ПРЕДОПЕРАЦИОННОЙ ДЕКОМПРЕССИИ ОБЩЕГО ЖЕЛЧНОГО ПРОТОКА
}

\begin{abstract}
Цель работы: выяснить динамику показателей гепатодепрессивного, цитолитического и холестатического синдромов, а также частоту осложнений у больных с механической желтухой опухолевого генеза после эндоскопической и лапароскопической предоперационной декомпрессии общего желчного протока.

Материалы и методы. В основу работы положен анализ историй болезней 60 больных с опухолями билиопанкреатодуоденальной зоны с синдромом механической желтухи, которые находились на лечении в ГУ “Национальный институт хирургии и трансплантологии имени А. А. Шалимова” АМН Украины с 2011 по 2017 г. Всем пациентам выполнена декомпрессия общего желчного протока как первый подготовительный этап с последующим радикальным оперативным вмешательством с лапаротомного доступа. В первой группе выполняли эндоскопическую декомпрессию желчных путей, заводя катетер ретроградно через большой дуоденальный сосочек. Во второй группе лапароскопически выполняли холецистэктомию, а дальше катетер заводили антеградно через пузырный проток. Дополнительно через правое подреберье дренировали ложе желчного пузыря. Основное оперативное вмешательство выполняли не ранее, чем через 14 суток. Всем пациентам выполняли общеклинические, специальные, лабораторные и инструментальные методы обследования. До операции, а также через 3 , 7 и 14 суток у пациентов в сыворотке крови общеизвестными методами определяли маркеры гепатодепрессивного, цитолитического и холестатического синдромов: содержание общего билирубина, активность аланинаминотрансферазы (АЛТ), щелочной фосфатазы (ЛФ), протромбиновое время, а также частоту осложнений в отдаленном послеоперационном периоде.

Результаты иссследований и их обсуждение. У всех пациентов с обтурационным холестазом опухолевого происхождения на время госпитализации отмечали увеличение показателей - маркеров гепатодепрессивного, цитолитического и холестатического синдромов. В ходе выполнения декомпрессии, независимо от способа, до 14 суток существенно падала активность в сыворотке крови АЛТ и ЛФ, снижалось содержание общего билирубина, а также величина ПВ, не достигали уровня общепринятой нормы. По большинству исследуемых маркеров холестаза эффективность обоих методов декомпрессии общего желчного протока была практически одинаковой, однако величина ПВ после лапароскопической декомпрессии через 14 дней была существенно меньше. В отдаленном послеоперационном периоде после лапароскопической декомпрессии частота осложнений была в 5,33 раза меньше, чем после эндоскопического вмешательства, что позволяет рекомендовать широкое внедрение лапароскопических технологий с целью декомпрессии желчных путей как первого этапа перед радикальным удалением опухолей билиопанкреатодуоденальной зоны.
\end{abstract}

Ключевые слова: лапароскопическая декомпрессия; обтурационный холестаз; периампулярна опухоль; маркеры холестаза. 